\title{
Accounting
}

\section{The effects of accounting benefit, ERP system quality and management commitment on accountants' satisfaction}

\author{
Thanh Hung Nguyen ${ }^{a *}$, Quynh Trang Nguyena and Le Dinh Hoang Vu
}

${ }^{a}$ Faculty of Accounting and Auditing, Thuongmai University, Vietnam

\begin{tabular}{l}
\hline C H R O N I C L E \\
\hline Article history: \\
Received: July 28, 2020 \\
Received in revised format: \\
July 302020 \\
Accepted: October 2, 2020 \\
Available online: \\
October 2, 2020 \\
\hline Keywords: \\
Accounting benefit \\
Accountant satisfaction \\
ERP system quality \\
Management commitment
\end{tabular}

\section{A B S T R A C T}

Enterprise Resource Planning (ERP) systems are the largest software packages of information systems adopted by many organizations all over the world. The utilization of ERP systems has been considered as a key determinant of competitive advantages. The main objective of the present study is to propose a model of the accountant's satisfaction in using enterprise ERP systems. Data were collected by using a questionnaire survey of almost 225 accountants working from 42 large Vietnamese construction firms. The results show that accounting benefits, ERP system quality and management commitment had significant effects on accountant's satisfaction in the ERP environment. The study also indicate that the management commitment had an impact on ERP system quality and ERP system quality had a positive relationship with accounting benefits as well. Based on these findings, implications for managers in Vietnamese construction firms in providing accounting information quality are discussed.

\section{Introduction}

Over the past few years, companies around the world have implemented enterprise resource planning (ERP) systems since the utilization of ERP systems has been considered as a key determinant of competitive advantages (Dezdar, 2017). In the context of industry 4.0, the ERP system is one of the modern management tools applied by businesses in popularity. The objective of the ERP system is to collect sufficient information on the operation of the organization to ensure the number of resources including financial resources, human resources, materials, machinery, etc., which meets the requirements of companies, through the use of planning tools and detailed planning (Davenport \& et al., 2004). ERP systems have significantly changed the way how business data is collected, stored, disseminated, and used. This change in information processing orientation affects the accounting process (Sutton, 2006). Successful implementation of ERP systems will have advantages in different aspects and departments in the enterprises. In recent years, Viet Nam's construction enterprises (VCEs) have made great achievements and important contributions to the country's socio-economic development (General Statistics Office of Viet Nam, 2019). With the characteristics of construction enterprises along with a large operating area, resources on assets and humans are scattered. In addition, there are various affiliated divisions and many departments participating in the construction process of enterprises. Therefore, the finance and accounting department plays a very important role in mobilizing and allocating resources, providing useful information to the managers who manage and operate the organizations effectively. According to the trend of Industry 4.0, Vietnamese construction enterprises have been effectively implementing information technology applications with ERP systems in management and operation activities. The increase in the number of ERP users in Vietnamese construction * Corresponding author.

E-mail address: thanhhungnguyen@tmu.edu.vn (T. H. Nguyen) 
enterprises, which is considered as an empirical evidence of the accountant's satisfaction in using the ERP system. Accountants on a daily basis will have an interaction with the ERP system so that they will realize the benefits from the use of ERP systems directly, which leads to their satisfaction. The previous research has been mentioned empirical evidence about accounting benefits perceived by users (Spathis \& Constantinides, 2004; Spathis, 2006; Kanellou \& Spathis, 2013). However, the model of the accountant's satisfaction related to accounting benefit, the relationship between ERP system quality and management commitment have rarely been empirically examined. With the development of the ERP system, the demand for corporate governance in the ERP environment will increase. Following this trend, this study focuses on factors affecting the accountant's satisfaction using ERP. The purpose of the study will, therefore, (1) analyze the impact of management commitment on ERP system quality, also examine the relationship between ERP system quality and accounting benefits perception; (2) assess the effect of accounting benefits, ERP system quality and management commitment on the accountant's satisfaction in Vietnam construction enterprises.

The remainder of this paper is structured as follows: the next section mentions the conceptual background and presents the research hypothesis of the study. Next, we describe the methodology employed for the research. After that, the process data analysis is presented, including descriptive statistics, measurement model, the structural model and hypothesis testing. In the next section, we show a discussion of the findings and finally, conclusions and recommendations drawn from this research are discussed including potential issues for further research and limitation of the research.

\section{Conceptual Background}

\subsection{Accounting benefits}

With ERP system, accounting modules are always considered as one of the most important modules with the reason of providing necessary information for managers about accounts receivable/payable, cash management, cost control and budgeting (Nicolaou, 1999). In the relevant literature, there are research studies focusing on the interaction between ERP systems and accounting. Spathis and Constantinides (2004) examined the reasons of enterprises making the decision to apply ERP systems and explored the changes that occur in terms of accountant applications. The results showed that the three most important motives that led to the increasing demand of ERP adoption for real-time information, information generation for decisionmaking and the need for integration of applications. The most highly-rated perceived benefits for accounting due to ERP implementation were increased flexibility in information generation, improved quality of reports, increased integration of accounts applications and improved decisions based on timely and reliable accounting information. These results are consistent with studies of the Spathis and Ananiadis (2005) and Kanellou and Spathis (2007). Olhager and Selldin (2003) suggested that companies that adopted an ERP system has been improving accounting benefits from the information perspective. According to this research, ERP implementation improved the availability of information, the integration of business procedures and functions and the quality of information. Spathis's study (2006) was to explore 17-accounting benefits involved in adopting ERP, and the relation between accounting benefits and reasons for applying ERP in companies that operate in Greece. Besides, the research adopted also Shang and Seddon's (2002) benefits classification in order to classify and examine accounting benefits with four benefits: organizational accounting benefits, operational accounting benefits, managerial accounting benefits and IT accounting benefits. The main accounting benefits are focused on organizational and operational dimensions, with benefits such as increased internal communication, improved decisions based on timely and reliable accounting information and improved quality of reports. From the relevant literature, it can be concluded that ERP systems implementation has an impact on the accounting processes, and has the relationship between accounting benefits with the adoption of ERP systems.

\subsection{ERP system quality}

System quality is defined as the degree in which the functionalities of the system can satisfy the needs of the users, with ease and encountering minimal problems (Delone \& McLean, 2003). These functional features include ease of use, accuracy, reliability, timeliness, response time, flexibility, integration (DeLone \& McLean, 2003; Nelson et al., 2005). In the ERP environment, according to Zhang et al. (2005), the ERP system quality consists of its flexibility, ease of use, reliability, short response time and useful (suitable) specific functions. Ifinedo and Nahar (2007) presented the characteristics of flexibility, ease of use, ease of learning and integration to define the quality of the ERP system.

\subsection{Management commitment}

Management commitment is defined as engaging in and maintaining behaviors that assist others to achieve a goal (Cooper, 2006). Management commitment in using ERP systems is related to investing and upgrading of information technology system, which will be ready to provide the necessary resources and authority to the successful implementation of the project (Hemanth, 2013). According to Zhang et al. (2005), management commitment related to the implementation of ERP project has two main 
aspects: (1) supplying the necessary resources and providing leadership, and (2) establishing rational objectives for the ERP implementation. They will facilitate the successful implementation of ERP in the organization. The commitment and support from management should not stop at the initiation and facilitation stage, but it is necessary to continue throughout the entire ERP implementation process. That is an important factor that leads to ERP system quality (Al-Mashari, 2003).

\subsection{Users Satisfaction}

User satisfaction refers to "recipient response to the use of the output of an information system", or the degree to which users feel the information system meets their requirements (DeLone \& McLean, 1992). Calisir and Calisir (2004) supposed that user satisfaction is measured by the perception of ease of use and design of the system. The ease of use and quality of information generated by the system is believed to be the factor that determines the level of user satisfaction of the system. Doll and Torkzadeh (1988) have considered user satisfaction in terms of system quality and information quality. They are of the opinion that systems that better meet the information requirements of the users, easier to use and eliminate errors, will have more satisfied users. An ERP is a complicated information system since it involves almost all business processes, while users' requirements for an ERP also cover all business processes, across vertical levels or horizontal sectors (Somers et al., 2003). Thus, the definition of user satisfaction in the present study is the user's awareness of the degree of matching between their requirements and ERP functionality.

\section{Hypothesis development}

\subsection{The effect of accounting benefits on accountant satisfaction}

For accountants when using ERP systems, their satisfaction comes from the accounting benefits of ERP application. Like any other tool, when more benefits the systems give, more satisfied users get. Regarding to accounting benefits, there are two directions that affect user's satisfaction. The first thing is the number of accounting benefits, and the second is the level of perception users about accounting benefits. This means that the accounting benefits affect user satisfaction (Spathis \& Ananiadis, 2005). Weli's study has assessed the satisfaction of accountants in using an ERP system. Research results have shown that accounting benefits, operational benefits, and managerial benefits are indicators which measure accountant's satisfaction in Indonesia enterprises (Weli, 2018). The accounting benefits is one of the important factors that create the ERP user satisfaction. The accounting benefit that becomes the highest benefit is to assist the accountant in completing financial reporting activities. Kanellou and Spathis (2013) also showed a strong correlation between ERP system users' satisfaction and accounting benefits, inside, the user includes accountants and ITs. This study was conducted in Greece and only concerns Greek companies. Research has divided accounting benefits into five dimensions: IT accounting benefits, operational accounting benefits (time), operational accounting benefits (cost), organizational accounting benefits and managerial accounting benefits. Their research indicates that "IT accounting benefits," "operational accounting benefits (time)," are related positively and significantly with ERP user satisfaction. Some other studies of Spathis and Constantinides (2004), Spathis (2006) with the empirical evidence also prove that there is a relationship between the accounting benefits and ERP user's satisfaction. In our study, we will evaluate the satisfaction of the accountant, who is related directly to the use of the ERP system. Therefore, we hypothesize the first hypothesis:

\section{H1: Accounting benefits has influences on accountant satisfaction.}

\subsection{The effect of ERP system quality}

System quality has a relationship with accounting benefits because it concerns the gathering of raw data in order to create the output from the accounting information system (DeLone \& McLean, 1992). System quality is also linked to managerial accounting benefits because of the increasing use of financial ratio aims at improving the output and creating information. Besides, the quality of the information system in the ERP environment provided useful information to support strategic planning, operational planning, decision-making and general information reporting (Booth et al., 2000). Therefore, the quality of the ERP system has an impact on accounting benefits, in terms of management accounting. On this basis, this study proposes the second hypothesis:

\section{H2: ERP system quality has influences on accounting benefits.}

Various researchers have been studying the effect of system quality in user's satisfaction through using different information system types (Costa et al., 2016). According to Urbach et al. (2010), system quality was considered as the most significant dimension in order to explain user's satisfaction. In the case of ERP systems research, this relationship between these two dimensions ERP system quality \& user satisfaction, is also known as an accurate perspective. System quality is indeed an important determinant of user's satisfaction with the ERP system (Chien \& Tsaur, 2007; Tsai et al., 2012; Abu-Shanab \& Saleh, 
2014). Higher system quality is expected to lead to higher user's satisfaction and utilization, which creates positive impacts on organizational productivity. Therefore, we expect that the ERP system quality has a positive influence on user's satisfaction. Therefore, we hypothesize:

H3: ERP system quality has an influence on accountants' satisfaction.

\subsection{The effect of management commitment}

Guimaraes et al. (2003) and Sabherwal et al. (2006) confirmed that the participation of the manager in implementing of the project and in defining its objectives can lead to a high-quality system. In the context of ERP, Wang and Chen (2006) showed that management commitment influences indirectly in ERP system quality via its positive impact on conflict resolution during the implementation and operation process. Hence, we put forward the following hypothesis:

\section{H4: Management commitment to the ERP implementation project has influences on ERP system quality.}

Management commitment encourages positive user's attitudes towards ERP systems (Hirt \& Swanson, 2001; Wang \& Chen, 2006). Consequently, high levels of management commitment may result in higher the user's perception of the effectiveness of ERP systems and promote their more success of users. This leads to user's satisfaction with ERP systems (Lin, 2010). On the other hand, when top management is committed to an ERP implementation, they can mobilize the resources required for consultants and put the ERP project on the top priority. Hence, the user's willingness to learn the new system and participate in the project is likely to increase (Wang \& Chen, 2006). So that, users can use effectively ERP implemented modules and they can fully perceive the benefits form the ERP system. As well as, they feel more satisfied when using the ERP system. Therefore, we hypothesize:

H5: Management commitment to the ERP implementation project has an influence on accountant satisfaction.

Given the above research hypotheses, the theoretical framework was developed in Fig. 1

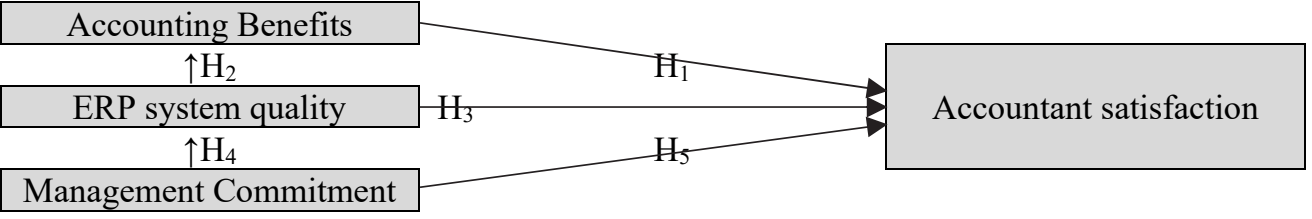

Fig. 1. Theoretical framework of the study

\section{4, Research methodology}

\subsection{Data collection}

The research methodology used in this study is a survey method. More specifically, this is a questionnaire survey which was utilized to collect empirical data for this study. To collecting data, a survey was carried out in Vietnamese construction enterprises that have implemented an ERP system for more than 2 years. In this study, we only surveyed accountants and chief accountant in VCEs, who directly used the ERP system and have to use an ERP system for 1 year or more. By personal relationships, the research invited potential respondents who are friends of the author, or former student working in VCEs. The questionnaire is sent to the survey subjects (respondents) via two methods: (1) print the paper survey and give directly to respondents; (2) send the survey form via email. Answers were collected between February 2020 and July 2020 . The distribution of totally 395 questionnaires to accountants who had implemented an enterprise system at least 1 year ago participated in the survey. These respondents continued to ask their colleagues to answer the questionnaire. At the end of the survey period, we received 262 surveys, from 42 construction enterprises, with an effective response rate of $66.3 \%$. 37 responses were found incomplete, and 225 were considered valid. The reason for the high response rate of this study because we only asked acquaintances to answer the survey. The descriptive statistical analyses are performed with the support of SPSS 22.0 and AMOS 22.0. The sample characteristics are shown in Fig. 2. Fifty-three percent of the respondents bought the ERP package from a local ERP system vendor and forty-seven percent of respondents used foreign ERP system vendors. ERP software usage rates between local vendors and foreign vendors are similar. Regarding job level, the table shows that $78.7 \%$ of the samples are nonmanager, $22.3 \%$ of the samples are managers or heads of sections. The majority of participants had a bachelor degree (65.8\%), followed by $17.8 \%$ diploma degrees. The minority of participants had a master degree (14.2\%). The least number of participants had a PhD degrees (2.2\%). About ERP experience, 32 participants (14.2\%) had less than 2 years of experience, followed by 
$56.0 \%$ from 2 to 5 years of experience. Nearly $30 \%$ of our respondents have experience using an ERP system for more than 5 years. Thus, almost of the participants have less than 5 years of experience.
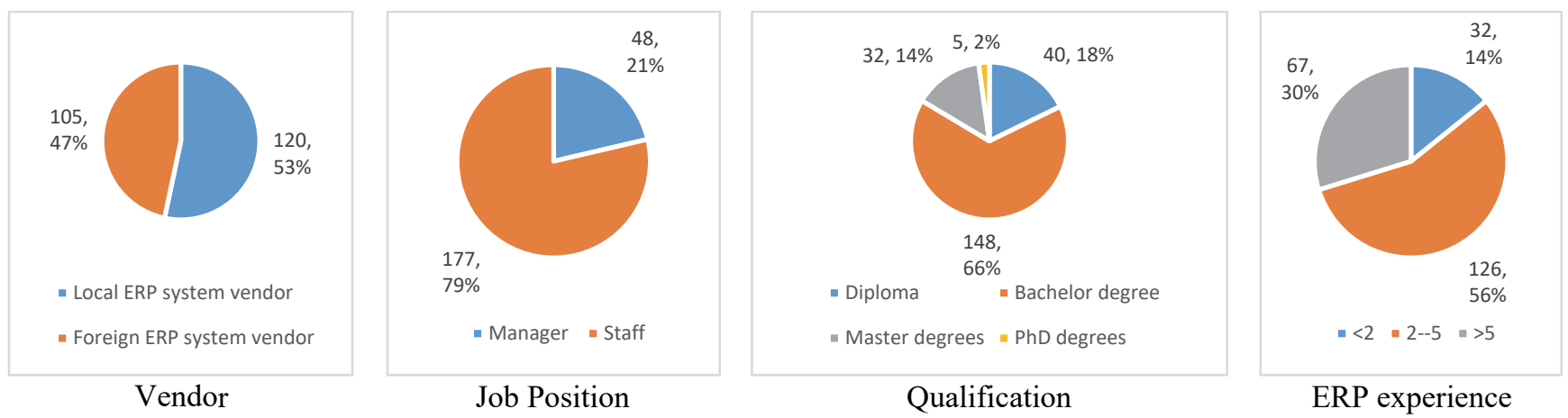

Fig. 2. Personal characteristics of the participants

\subsection{Measures}

All research constructs included in this study have multi-item scales derived from relevant prior research. Each item in the survey employed a 5 -point Likert scale ( $1=$ Completely disagree, $5=$ Completely agree). The high score shows respondents perceive high value, vice versa.

Accounting benefits: As a theoretical foundation for our research, we adopted Shang and Seddon's (2002) benefits classification and accounting benefits are divided into four dimensions: organizational accounting benefits, operational accounting benefits, management accounting benefits, IT accounting benefits. Accounting benefits were based on scales used by Spathis (2006), Kanellou \& Spathis (2011) and Shang \& Seddon (2002).

ERP system quality: ERP system quality items were measured in the manner of DeLone and Mclean (2003), Nelson et al. (2005), and reformulated by Lin (2010). In which, ERP system quality consists of dimensions of reliability, response time, integration data, task performance and ease of access.

Management commitment: management commitment measured the extent to which top management involved and provided the resources and authority required for ERP implementation and was adapted from Wang \& Chen (2006) and Lee \& Kim (1992).

Accountant satisfaction: We use a user satisfaction scale to measure the satisfaction of the accountant, who is end-users of the ERP system. Satisfaction with the ERP system was measured with a 4-item scale based on DeLone and Mclean (2003) and Lin (2010). The four items assessed the extent to which respondents feel satisfied with the information received from the ERP system, their interaction with the system, elimination of errors or significant distractions, and global satisfaction with the ERP system.

The questionnaire was translated from the English language to the Vietnamese language using the back-to-back technique to ensure the meanings are the same as the original. Then, the initial questionnaire was pilot tested on 56 respondents including accountants in VCEs, based on their responses, some items were revised for clarity. We eliminated unsuitable scales using content analysis and tested by Cronbach Alpha test and Corrected item-total correlation. All the measures are provided in Appendix A.

\section{Data analysis and hypothesis testing}

\subsection{Measurement model}

We estimate the reliability, convergent and discriminant validity of each measurement scale to assess the measurement model. Firstly, the results of the reliability analysis showed that all factors had Cronbach's Alpha coefficient greater than 0.7. Then, the observed variables were factor analyzed (based on free loadings) using Principal Component Analysis (PCA) with varimax rotation as a commonly used technique for summarizing a set of variables into independent subsets. The KMO coefficient is greater than 0.5, the Bartlett test has a p-value less than 0.05, the Eigenvalue coefficient $>1$, all factor loadings are greater than the typical cutoff value of 0.5 (Hair et al., 2010) and significant at the $p<.001$ level. In addition to the Cronbach's alpha values, Composite Reliability (CR) was also tested and the acceptable value of CR is 0.7, as suggested by Fornell and Larcker (1981), 
implying high internal consistency. In assessing the discriminant validity, the square root of the average variance extracted (AVE) for each construct, which provides a measure of the variance shared between a construct and its indicators, is greater than 0.5 . In summary, the convergent and discriminant validity of the data was psychometrically adequate for this study (Fornell \& Larcker, 1981). The results are presented in Table 1.

Table 2

Reliability and convergent validity test

\begin{tabular}{|c|c|c|c|c|c|}
\hline Construct (variable) & $\begin{array}{l}\text { Indicator } \\
\text { (Items) }\end{array}$ & $\begin{array}{l}\text { Factor } \\
\text { Loading }\end{array}$ & Cronbach's Alpha & $\begin{array}{c}\text { Composite } \\
\text { Reliability (CR) }\end{array}$ & $\begin{array}{c}\text { Average } \\
\text { Variance } \\
\text { Extract (AVE) }\end{array}$ \\
\hline \multicolumn{6}{|l|}{ Accounting benefits (ABE) } \\
\hline \multirow{5}{*}{ Organizational accounting benefits (ABE_ORG) } & A_ORG1 & 0.788 & \multirow{5}{*}{0.871} & \multirow{5}{*}{0.874} & \multirow{5}{*}{0.582} \\
\hline & A ORG2 & 0.808 & & & \\
\hline & A ORG3 & 0.834 & & & \\
\hline & A_ORG4 & 0.714 & & & \\
\hline & A ORG5 & 0.822 & & & \\
\hline \multirow{5}{*}{ Operational accounting benefits (ABE_OPE) } & A_OPE1 & 0.778 & \multirow{5}{*}{0.865} & \multirow{5}{*}{0.878} & \multirow{5}{*}{0.577} \\
\hline & A OPE2 & 0.727 & & & \\
\hline & A_OPE3 & 0.725 & & & \\
\hline & A OPE4 & 0.795 & & & \\
\hline & A_OPE5 & 0.891 & & & \\
\hline \multirow{3}{*}{ Managerial accounting benefits (ABE_MAN) } & A_MAN1 & 0.723 & \multirow{3}{*}{0.700} & \multirow{3}{*}{0.720} & \multirow{3}{*}{0.518} \\
\hline & A MAN2 & 0.806 & & & \\
\hline & A MAN3 & 0.763 & & & \\
\hline \multirow[t]{2}{*}{ IT accounting benefits (ABE_IT) } & A IT1 & 0.822 & \multirow{2}{*}{0.807} & \multirow{2}{*}{0.807} & \multirow{2}{*}{0.676} \\
\hline & A IT2 & 0.796 & & & \\
\hline \multirow[t]{5}{*}{ ERP system quality (ESQ) } & ESQ1 & 0.707 & \multirow{5}{*}{0.828} & \multirow{5}{*}{0.827} & \multirow{5}{*}{0.510} \\
\hline & ESQ2 & 0.759 & & & \\
\hline & ESQ3 & 0.784 & & & \\
\hline & ESQ4 & 0.796 & & & \\
\hline & ESQ5 & 0.779 & & & \\
\hline \multirow[t]{4}{*}{ Management commitment (MAC) } & MAC1 & 0.778 & \multirow{4}{*}{0.832} & \multirow{4}{*}{0.839} & \multirow{4}{*}{0.570} \\
\hline & MAC2 & 0.843 & & & \\
\hline & MAC3 & 0.757 & & & \\
\hline & MAC4 & 0.881 & & & \\
\hline \multirow[t]{4}{*}{ Accountant satisfaction (ACS) } & ACS1 & 0.857 & \multirow{4}{*}{0.882} & \multirow{4}{*}{0.884} & \multirow{4}{*}{0.655} \\
\hline & $\mathrm{ACS} 2$ & 0.865 & & & \\
\hline & ACS3 & 0.867 & & & \\
\hline & ACS4 & 0.856 & & & \\
\hline
\end{tabular}

\subsection{Structural equation modeling analysis and hypothesis testing}

The proposed structural model was examined using AMOS 22.0 software. The analysis of structural equation modeling showed that the model fits the data, Chi-square $/ \mathrm{df}=1.925<3$; CFI $=0.903$; TLI $=0.881$; GFI $=0.839$, were greater than 0.8 ; RMSEA $=0.064<0.08$, P.Value $=0.000<0.05$. Overall, the hypothesis structural model provided an acceptable fit for the data $($ Hair et al., 2010). The structural model's quality was evaluated by using bootstrapping, a resampling technique that draws a large number of subsamples retrieved from the original dataset. In this case, 10000 subsamples were used to determine the path's significance within the structural model (Henseler et al., 2009). The structural model results can be observed in Fig.3. After establishing the validity of the structural model, the structural paths were assessed to test the research hypotheses. The result showed that accounting benefits (ABE), ERP system quality (ESQ), and management commitment (MAC) have positively influenced to accountant satisfaction (ACS). The coefficient $\mathrm{R}^{2}$ of the model is 0.418 which suggests that three factors explained $41.8 \%$ of the variance in the accountant's satisfaction. (see Table 2).

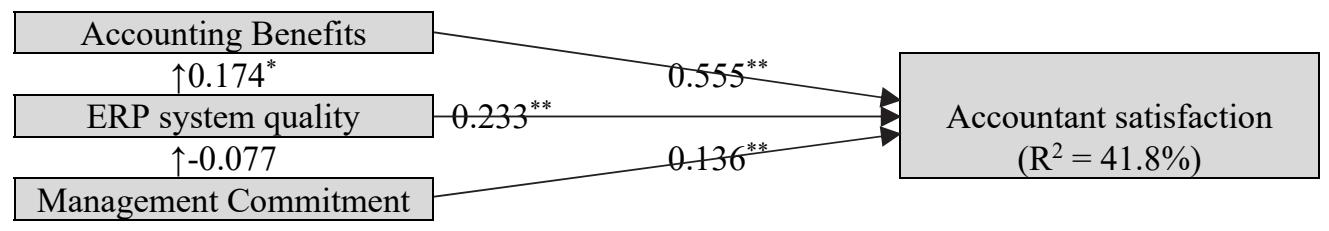

Notes: Path * significant at $p<.050, * *$ significant at $p<.005, * * *$ significant at $p<.001$

Fig. 3. Results of our proposed model 
Table 3

Regression analysis and hypothesis results

\begin{tabular}{|c|c|c|c|c|c|c|c|c|}
\hline \multicolumn{3}{|c|}{ Impact } & $\begin{array}{c}\text { Unstandardized } \\
\text { estimation }\end{array}$ & $\begin{array}{l}\text { Standardized } \\
\text { estimation }\end{array}$ & S.E & C.R & $\mathrm{P}$ & $\mathrm{R}^{2}$ \\
\hline $\mathrm{ACS}$ & $\leftarrow$ & $\mathrm{ABE}$ & 0.699 & 0.555 & 0.135 & 5.176 & $* * *$ & \\
\hline ACS & $\leftarrow$ & ESQ & 0.348 & 0.233 & 0.110 & 3.155 & 0.002 & 0.418 \\
\hline ACS & $\leftarrow$ & MAC & 0.126 & 0.136 & 0.061 & 2.069 & 0.039 & \\
\hline $\mathrm{ABE}$ & $\leftarrow$ & ESQ & 0.207 & 0.174 & 0.104 & 1.995 & 0.046 & \\
\hline ESQ & $\leftarrow$ & MAC & -0.047 & -0.077 & 0.049 & -0.974 & 0.330 & \\
\hline
\end{tabular}

In Hypothesis 1, it is posited that accounting benefits would have a significant effect on the accountant's satisfaction. The coefficient for the path from ABE to ACS is positive and significant $(\beta=0.555, \mathrm{p}<0.001)$ which supports hypothesis H1.

In Hypothesis 3, it is hypothesized that the ERP system quality would have a significant effect on the accountant's satisfaction. The results show that this hypothesis is supported $(\beta=0.233, \mathrm{p}<0.005)$.

Hypothesis 5 proposes that management commitment to the ERP implementation project has an influence on the accountant's satisfaction. The coefficient for the path from MAC to ACS is positive and significant $(\beta=0.136, p<0.005)$ which supports hypothesis H5. Confirming hypotheses H1, H3 and H5, we can conclude that accounting benefits $(\beta=0.555)$, ERP system quality $(\beta=0.233)$, and management commitment $(\beta=0.136)$ had a significant effect on the accountant satisfaction (ACS).

We have hypothesis 2 with a weak linkage between ERP system quality and accounting benefits in terms of statistical significance $(\mathrm{p}<0.05)$, and in small effect with $\beta=0.174$ With P.value $<0.05, \mathrm{H} 2$ is supported. In contrast to the predictions of $\mathrm{H} 4$, management commitment to the ERP implementation project (MAC) is not significant for the effects on ERP system quality (ESQ). The coefficient for the path from MAC to ESQ is negative and non-significant $(\beta=-0.077, p=0.330)$ which does not support Hypothesis 4.

\section{Discussion}

The objective of this paper was to test empirically the influence of accounting benefits, ERP system quality and management commitment on the satisfaction level of end-users who are accountants in VCEs. Firstly, we found that accounting benefits have the largest effect on accountant satisfaction $(\beta=0.555)$. The results of this study are also in accordance with research conducted by Kanellou and Spathis (2011) in Greece, Hénoc \& Rivera (2014) in France, Wili (2018) in Indonesia. These accounting benefits are measured by four dimensions, including operational accounting benefits, IT accounting benefits, organizational accounting benefits, managerial accounting benefits. End-user rated highest organizational accounting benefits and IT accounting benefits. The implementation of ERP has brought more accounting benefits. The higher the users appreciate the benefits of an ERP, the higher their satisfaction. Perceptions of accountant satisfaction increase through the important accounting benefits that occur for a company because the inclusion of the accounting department in the ERP system are increased business flexibility, increased integration of accounting applications, enhanced quality of reports, improved decisions-making process based on timely and reliable accounting information and reduction of time for transaction processing. Therefore, the results of the study help managers in construction enterprises have an overview and have a better understanding of the benefits that ERP brings to the accounting field. Consequently, it is necessary to have a level of assurance that these accounting benefits are going to be reached so the accountants are going to be satisfied with the implementation of EPRS. Since then, the working efficiency of accounting is enhanced, supporting managers to receive high-quality information.

Secondly, the ERP system quality is also positively associated with accountant satisfaction. ERP system reliability, response time, flexibility, integration and convenience of access are important factors that contribute to ERP user satisfaction. Besides, with ERP system quality, it can result in more exact task performance and a higher level of accountant satisfaction. The finding of the current study is consistent with results of studies conducted in developing countries such as Botswana (Uzoka et al., 2008), Jordan (Abu-Shanab \& Saleh, 2014), Taiwan (Hsu et al., 2015), Portugal (Costa et al., 2016) and Iran (Dezdar, 2017). Besides, the results of this study showed that ERP system quality has positively influence accounting benefits, in accordance with Booth et al. (2000), Spathis (2016). When an ERP system is implemented effectively, it will increase flexibility, functionality, reliability and integrated applications. It leads to extend managerial and IT accounting benefits. So that, the system provides completed, accurate and well-formatted information.

Thirdly, management commitment has an effect on the accountant's satisfaction. The results of this study are also in accordance with research conducted by Wang \& Chen (2006), Lin (2010). Management commitment has two major aspects in ERP system implementation: providing the necessary resources (personnel \& finance) and providing leadership for managing and controlling the processes of ERP implementation. With the commitment of managers, the ERP system operates stable, gathers data and processes results more quickly, reduction of errors. Moreover, management commitment motivates employees to strive for a 
continuous process of improvement, this leads to enhance accounting information quality. Therefore, End-user satisfaction in the accounting department is increased.

Concerning the effect of management commitment on the ERP system quality, the contribution of this variable has not been demonstrated in this relation. This may be explained by the fact that the users of ERP within a company/organization did not realize the impact of management commitment on ERP implementation and maintain a good ERP system. On the other hand, many enterprises had to temporarily stop implementing ERP system because they faced difficulties in human resources, finance, firm size, large area. Managers did not make commitments on training, sufficient funding for ERP implementation, and controlling the processes of ERP implementation and operation effectively. So that, respondents did not perceive the impact of management commitment on ERP system quality.

\section{Conclusions, limitations and future research}

We aimed in this research to determine how accounting benefits, ERP system quality, management commitment to effect accountant satisfaction, to improve the quality of accounting information. We, thus, used the SEM model to test these relations. The results obtained show that accounting benefits, ERP system quality, management commitment can be explained by $41.8 \%$ of changes in accountant satisfaction. Accountant satisfaction improves when enterprises create more accounting benefits, improve the quality of the ERP system and carry out management commitments. Contemporary, ERP system quality also improves when the top manager fulfills its commitment to recruiting the personnel, controlling the processes of ERP implementation, enhancing the performance of the ERP system. The results of this study contribute theoretical to ERP research and practical to ERP system users in terms of increasing user satisfaction of the ERP system. On a theoretical level, our work represents an attempt to explain accountant satisfaction by accounting benefits, ERP system quality, and management commitment in adopting ERP. To our knowledge, few studies have addressed the satisfaction of accountants in the accounting department in the ERP context. Our research has somewhat assessed the satisfaction of accountants, who play an important role in operating ERP systems to provide timely and flexible accounting information for decision-making. This study also contributes to the literature by building an end-user satisfaction model derived from the information software success models of DeLone and McLean (DeLone \& McLean, 2003). Furthermore, the results of this study will provide a stimulus for consequent research in the field in order to further examine and account for the accounting benefits that can occur from an ERP system implementation and whether or not these benefits have an impact on accountant's satisfaction. Like most empirical research, this study is not without limitations. First, the sample size of this study is relatively small (containing only 42 firms operating in Northern Vietnam). Meanwhile, the number of Viet Nam's construction enterprises implementing EARP is quite large, distributed in the southern of Vietnam. A larger sample that brings more statistical power would have allowed more sophisticated statistics analysis and more reliable. The second limitation concerns measurement scales. This study is based on subjective measures provided by the questionnaire survey, which depend on respondents' perceptions. This approach may cause some bias. However, the use of perceptions was considered appropriate for this research because most of the data required evaluating the research variables related to the perception of respondents. These are intangible in nature and it would be difficult, if not impossible, to collect them objectively. Taking into account these limitations, we can offer directions for future research. Future studies could explore the contribution of other contingency factors that may influence the accountant satisfaction, such as organizational culture and the usefulness of accounting information system. The study also did not assess the changes in the accountant satisfaction before and after applying of ERP system in VCEs. Therefore, these issues may be further clarified in further research.

\section{References}

Abu-Shanab, E.A., \& Saleh, Z. (2014). Contributions of ERP systems in Jordan. International Journal of Business Information Systems, 15(2), 244-260. https://doi.org/10.1504/IJBIS.2014.059255.

Al-Mashari, M. (2003). A process change - oriented model for ERP application. International Journal of Human-Computer Interaction, 16(1), 39-55. https://doi.org/10.1207/S15327590IJHC1601 4.

Booth, P., Matolcsy Z., \& Wieder., B. (2000). The impacts of enterprise resource planning systems on accounting practice: The Australian experience. Australian Accounting Review, 10(3), 4-18. https://doi.org/10.1111/j.1835-2561.2000.tb00066.x.

Calisir, F., \& Calisir, F. (2004). The relation of interface usability characteristics perceived usefulness, and perceived ease of use to end- user satisfaction with enterprise resource planning (ERP) systems. Computers in Human Behavior, 20(4), 505515. https://doi.org/10.1016/j.chb.2003.10.004.

Chien, S.-W., \& Tsaur, S.-M. (2007). Investigating the success of ERP systems: case studies in three Taiwanese high-tech industries. Computers in Industry, 58(8-9), 783-793. http://dx.doi.org/10.1016/j.compind.2007.02.001.

Cooper, D. (2006). The impacts management commitment on employee behaviour a field study. American Society of Safety Engineers Middle East Chapter, $7^{\text {th }}$ Proffesional Development Conference and Exhibition, March 18-22. 
Costa, C.J., Ferreira E., Bento F., \& Aparicio M. (2016). Enterprise resource planning adoption and satisfaction determinants. Computers in Human Behavior, 63, 659-671. https://doi.org/10.1016/j.chb.2016.05.090.

Davenport, T., Harris, J., \& Cantrell, S. (2004). Enterprise systems and ongoing process change. Business Process Management Journal, 10(1), 16-26. https://doi.org/10.1108/14637150410518301

DeLone, W., \& McLean, E. (1992). Information systems success: The quest for the dependent variable. Information Systems Research, 3(1), 60-95. http://dx.doi.org/10.1287/isre.3.1.60.

Delone, W. H., \& McLean, E. R. (2003). The DeLone and McLean model of information systems success: a ten-year update. Journal of Management Information Systems, 19(4), 9-30. https://doi.org/10.1080/07421222.2003.11045748.

Dezdar, S. (2017). An integrative model for realising benefits from enterprise resource planning implementation. International Journal Business Information Systems, 24(4), 423-451. https://doi.org/10.1504/IJBIS.2017.082887.

Doll, W. J., \& Torkzadeh, G. (1988). The measurement of end-user computing satisfaction. MIS Quarterly, 12(2), $259-274$. https://doi.org/10.2307/248851.

Fornell, C., \& Larcker, D. (1981). Evaluating structural equation models with unobservable variables and measurement error. Journal of Marketing Research, 18(1), 39-50. https://doi.org/10.1177/002224378101800104.

General Statistics Office of Viet Nam (2019). Report construction production and business trends in the third quarter and forecast for the fourth quarter of 2019, https://www.gso.gov.vn/Default.aspx?tabid=382\&ItemID=19361 (accessed 15 July 2020)

Guimaraes, T., Staples, D.S., \& McKeen, J.D. (2003). Empirically testing some main user-related factors for systems development quality. Quality Management Journal, 10(4), 39-54. https://doi.org/10.1080/10686967.2003.11919083.

Hemanth, K. M. (2013). Critical success factors for the implementation of Peoplesoft enterprise resource planning in a Public organization, Dissertations. Published by ProQuest LLC, Wilmington University.

Henseler, J., Ringle, C. M., \& Sinkovics, R. R. (2009). The Use of Partial Least Squares Path Modeling in International Marketing. Advances in International Marketing (AIM), 20, 277-320. Available at SSRN: https://ssrn.com/abstract=2176454.

Hénoc, S., \& Rivera, A. (2014). Enterprise Resource Planning Systems and Users' Satisfaction - A study of French companies. Master Thesis.

Hirt, S.G., \& Swanson, E.B. (2001). Emergent maintenance of ERP: New roles and relationships. Journal of Software Maintenance: Research and Practice, 13, 373-397. https://doi.org/10.1002/smr.238.

Hsu, P.-F., Yen, H.J.R., \& Chung J.-C. (2015). Assessing ERP post-implementation success at the individual level: revisiting the role of service quality. Information and Management. http://dx.doi.org/10.1016/j.im.2015.06.009

Lee, J.N., \& Kim, S. (1992). The relationship between procedural formalization in MIS development and MIS success. Information and Management, 22(2), 89-111. https://doi.org/10.1016/0378-7206(92)90064-M.

Lin, H.-F. (2010). An investigation into the effects of IS quality and top management support on ERP system usage. Total Quality Management \& Business Excellence, 21(3), 335-349, https://doi.org/10.1080/14783360903561761.

Kanellou, A., \& Spathis, C. (2013) Accounting benefits and satisfaction in an ERP environment. International Journal of Accounting Information Systems, 14, 209-234. https://doi.org/10.1016/j.accinf.2012.12.002.

Ifinedo, P.E., Nahar, N. (2007). ERP systems success: an empirical analysis of how two organizational stakeholder groups prioritize and evaluate relevant measures. Enterprise Information Systems, 1(1), 25-48. http://dx.doi.org/10.1080/17517570601088539.

Nelson, R.R., Todd, P.A., \& Wixom, B.H. (2005). Antecedents of information and system quality: An empirical examination within the context of data warehousing. Journal of Management Information Systems, 21(4), 199-235. https://doi.org/10.1080/07421222.2005.11045823.

Nicolaou, A.I. (1999). Accounting Information Systems, Vol. I, Benou Publishers, Athens.

Olhager, J., \& Selldin, E. (2003). Enterprise resource planning survey of Swedish manufacturing firms. European Journal of Operational Research, 146(2), 365-373. https://doi.org/10.1016/S0377-2217(02)00555-6.

Sabherwal, R., Jeyaraj, A., \& Chowa, C. (2006). Information system success: individual and organizational determinants. Management Science, 52(12), 1849-1864. http://dx.doi.org/10.1287/mnsc.1060.0583.

Shang, S., \& Seddon, P.B. (2002). Assessing and managing the benefits of enterprise systems: the business manager's perspective. Information Systems Journal, 12(2), 271-299. https://doi.org/10.1046/j.1365-2575.2002.00132.x.

Somers, T., Nelson, K., \& Karimi, J. (2003). Confirmatory factor analysis of the end-user computing satisfaction instrument: Replication within an ERP domain. Decision Sciences, 34(3), 595-621. https://doi.org/10.1111/j.1540-5414.2003.02428.x.

Spathis, C. (2006). Enterprise systems implementation and accounting benefits. Journal of Enterprise Information Management, 19(1), 67-82. https://doi.org/10.1108/17410390610636887.

Spathis, C., \& Ananiadis, J. (2005). Assessing the benefits of using an enterprise system in accounting information and management. Journal of Enterprise Information Management, $18(2), \quad 195-210$. https://doi.org/10.1108/17410390510579918.

Spathis, C., \& Constantinides, S. (2004). Enterprise resource planning systems' impact on accounting processes. Business Process Management Journal, 10(2), 234-247. https://doi.org/10.1108/14637150410530280. 
Sutton, S.G. (2006). Enterprise systems and the re-shaping of accounting systems: a call of research. International Journal of Accounting Information Systems, 7(1), 1-6. https://doi.org/10.1016/j.accinf.2006.02.002.

Tsai, W.-H., Lee, P.-L., Shen, Y.-S., \& Lin, H.-L. (2012). A comprehensive study of therelationship between enterprise resource planning selection criteria and enterprise resource planning system success. Information \& Management, 49(1), 36-46. http://dx.doi.org/10.1016/j.im.2011.09.007.

Urbach, N., Smolnik, S., \& Riempp, G. (2010). An empirical investigation of employee portal success. The Journal of Strategic Information Systems, 19(3), 184-206. http://dx.doi.org/10.1016/j.jsis.2010.06.002.

Wang, E., Chen, J. (2006). Effects of internal support and consultant quality on the consulting process and ERP system quality. Decision Support Systems, 42(2), 1029-1041. http://dx.doi.org/10.1016/j.dss.2005.08.005.

Weli (2018). The accountant satisfaction in using ERP systems. Communication \& Information Technology Journal 12(1), 2734. https://doi.org/10.21512/commit.v12i1.4242.

Zhang, Z., Leeb, M.K.O., Huang, P., Zhang, L., \& Huang, X. (2005). A framework of ERP systems implementation success in China: an empirical study. International Journal of Production Economics, 98(1), 56-80. http://dx.doi.org/10.1016/j.ijpe.2004.09.004.

\section{Appendix A}

Measurement items

\begin{tabular}{|c|c|c|c|}
\hline Construct & Code & Indicator & Reference \\
\hline \multicolumn{4}{|l|}{$\begin{array}{l}\text { Accounting benefits } \\
\text { (ABE) }\end{array}$} \\
\hline \multirow{5}{*}{$\begin{array}{l}\text { Organizational accounting } \\
\text { benefits (ABE_ORG) }\end{array}$} & A_ORG1 & Increased internal communication & \multirow{5}{*}{$\begin{array}{l}\text { Spathis (2006), Shang \& } \\
\text { Seddon (2002) }\end{array}$} \\
\hline & A_ORG2 & Improved co-ordination between departments & \\
\hline & A_ORG3 & Improved decisions based on timely and reliable accounting information & \\
\hline & A_ORG4 & Improved decision-making process & \\
\hline & A_ORG5 & Increased integration of accounting applications & \\
\hline \multirow{5}{*}{$\begin{array}{l}\text { Operational accounting } \\
\text { benefits (ABE_OPE) }\end{array}$} & A_OPE1 & Reduction of time for annual closing of accounts & \multirow{5}{*}{$\begin{array}{l}\text { Spathis (2006), Shang \& } \\
\text { Seddon (2002) }\end{array}$} \\
\hline & A_OPE2 & Reduction of time for issuing reports & \\
\hline & A_OPE3 & Reduction of accounting department personnel & \\
\hline & A_OPE4 & Improved quality of reports & \\
\hline & A OPE5 & Improved working capital control & \\
\hline \multirow{3}{*}{$\begin{array}{l}\text { Managerial accounting } \\
\text { benefits (ABE_MAN) }\end{array}$} & A_MAN1 & Increased flexibility in information generation & \multirow{3}{*}{$\begin{array}{l}\text { Spathis (2006), Shang \& } \\
\text { Seddon (2002) }\end{array}$} \\
\hline & A_MAN2 & Increased use of financial ratio analysis & \\
\hline & A MAN3 & Improved cash control - liquidity & \\
\hline \multirow{2}{*}{$\begin{array}{l}\text { IT accounting benefits } \\
\text { (ABE_IT) }\end{array}$} & A_IT1 & Reduction of time for transaction processing & \multirow{2}{*}{$\begin{array}{l}\text { Spathis (2006), Shang \& } \\
\text { Seddon (2002) }\end{array}$} \\
\hline & A_IT2 & Improved business flexibility & \\
\hline \multirow{5}{*}{$\begin{array}{l}\text { ERP system quality } \\
\text { (ESQ) }\end{array}$} & ESQ1 & The operation of ERP system is reliable & \multirow{5}{*}{$\begin{array}{l}\text { DeLone and Mclean } \\
\text { (2003), Nelson et al. } \\
(2005), \text { Hsiu-Fen Lin } \\
\text { (2010) }\end{array}$} \\
\hline & ESQ2 & The response time of ERP system is acceptable. & \\
\hline & ESQ3 & ERP system effectively integrates data from different areas of the company & \\
\hline & ESQ4 & ERP system exactly performs its tasks as required & \\
\hline & ESQ5 & ERP system makes information easy to access & \\
\hline \multirow[t]{4}{*}{$\begin{array}{l}\text { Management commitment } \\
\text { (MAC) }\end{array}$} & MAC1 & $\begin{array}{l}\text { Managers engages in recruiting the personnel needed for implementing and } \\
\text { operating the ERP system }\end{array}$ & \multirow[t]{4}{*}{$\begin{array}{l}\text { Wang \& Chen (2006), } \\
\text { Lee \& Kim (1992) }\end{array}$} \\
\hline & MAC2 & $\begin{array}{l}\text { Top management is much concerned with the performance of the ERP } \\
\text { system }\end{array}$ & \\
\hline & MAC3 & $\begin{array}{l}\text { Managers makes an effort to provide stable and sufficient funding for ERP } \\
\text { implementation and operation }\end{array}$ & \\
\hline & MAC4 & $\begin{array}{l}\text { Managers emphasizes managing and controlling the processes of ERP } \\
\text { implementation and operation effectively }\end{array}$ & \\
\hline \multirow{4}{*}{$\begin{array}{l}\text { Accountant satisfaction } \\
(\mathrm{ACS})\end{array}$} & ACS1 & The information I get from ERP system is very satisfying & \multirow{4}{*}{$\begin{array}{l}\text { DeLone and Mclean } \\
(2003), \text { Nelson et al. } \\
(2005), \text { Hsiu-Fen Lin } \\
(2010)\end{array}$} \\
\hline & ACS2 & My interaction with ERP system is very satisfying & \\
\hline & ACS3 & The ERP system has eliminated errors or significant distractions & \\
\hline & ACS4 & The ERP system satisfies me on the whole & \\
\hline
\end{tabular}

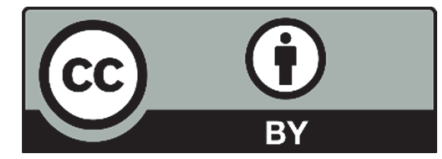

(C) 2020 by the authors; licensee Growing Science, Canada. This is an open access article distributed under the terms and conditions of the Creative Commons Attribution (CC-BY) license (http://creativecommons.org/licenses/by/4.0/). 